\title{
PROBLEMATIKA PENDIDIKAN KARAKTER PENDIDIKAN TINGGI
}

\author{
Dra. Ifham Choli, MM, MPd \\ ifhamcholi@yahoo.co.id
}

\begin{abstract}
Character education in higher education aims to improve the quality of implementation and educational outcomes that lead to the achievement of the formation of the character and noble character of students as a whole, integrated and balanced according to graduate competency standards. Through character education, students are expected to be able to independently improve and use their knowledge, study and internalize character values so that they are manifested in daily behavior. The implementation of character education has its own problems, namely the existence of unsynchronization between the concepts of character education, which aims to restore the culture and character of the nation which is increasingly deteriorating with the reality faced. Character education in higher education is everything done by a lecturer, able to influence the character of students. This includes many things about the exemplary of a lecturer be it behavior, speech, tolerance, integrity and others related to character. The campus environment as an escort institution for character building for students, has potentials that will contribute to the processes, so synergy is needed together in coaching from all campus residents. In teaching character building, lecturers can integrate it naturally with the standard curriculum or teach it in tandem with the standard curriculum. All lecturers in all subjects should be figures who practice the formation of this character in all activities in the classroom and outside the classroom.
\end{abstract}

Keywords: Problems, Education, Character, Higher Education

\begin{abstract}
Abstrak
Pendidikan karakter di perguruan tinggi bertujuan untuk meningkatkan mutu penyelenggaraan dan hasil pendidikan yang mengarah pada pencapaian pembentukan karakter dan akhlak mulia mahasiswa secara utuh, terpadu dan seimbang sesuai standar kompetensi lulusan. Melalui Pendidikan karakter diharapkan mahasiswa mampu secara mandiri meningkatkan dan menggunakan pengetahuannya, mengkaji dan menginternalisasi nilai-nilai karakter sehingga terwujud dalam perilaku sehari-hari. Pelaksanaan pendidikan karakter memiliki permasalahan tersendiri, yaitu adanya ketidaksinkronan antara konsep pendidikan karakter, yang bertujuan untuk mengembalikan budaya dan karakter bangsa yang semakin merosot dengan realita yang dihadapi. Pendidikan karakter di perguruan tinggi adalah segala sesuatu yang dilakukan oleh seorang dosen, mampu mempengaruhi karakter mahasiswa. Hal ini mencakup banyak hal tentang keteladanan seorang dosen baik itu perilaku, cara berbicara, hidup bertoleransi, berintegritas dan lain-lain yang berkaitan dengan karakter. Lingkungan kampus sebagai institusi pengawal character building para mahasiswa, memiliki potensipotensi yang akan berkontribusi pada proses-prosesnya, sehingga dibutuhkan kebersamaan secara sinergis dalam pembinaannya dari seluruh warga kampus. Dalam mengajarkan

\footnotetext{
${ }^{1}$ Dosen Tetap Program Studi Pendidikan Agama Islam Fakultas Agama Islam Universitas Islam As-Syafi'iyah Jakarta
}

57 ITahdzib Akhlaq No V/1/2020 
pembentukan karakter, dosen dapat mengintegrasikannya secara alami dengan kurikulum standar maupun mengajarkan beriringan dengan kurikulum standar. Semua dosen pada semua mata kuliah hendaknya menjadi figure yang mempraktekkan pembentukan karakter ini dalam semua aktivitas di kelas maupun di luar kelas.

Kata Kunci : Problematika, Pendidikan , Karakter, Pendidikan Tinggi

\section{A. Pendahuluan}

1. Latar Belakang Masalah

Pendidikan karakter adalah pendidikan sepanjang hayat, sebagai proses perkembangan ke arah manusia kaafah $^{2}$. Kita sering mendengar bahwa pendidikan karakter membutuhkan peran orang tua dan juga menjadi tanggung jawab semua guru. Kalimat tersebut mengisyaratkan bahwa Pendidikan karakter akan berhenti pada jenjang pendidikan tingkat Menengah Atas (SMA). Sedangkan istilah guru yang kita kenal seringkali berhenti pada definisi Guru sampai tingkat SMA. Belajar membentuk karakter yang kuat dan bertanggung jawab tidak hanya sebatas pada tingkat menengah saja, tetapi masih harus berkelanjutan sampai pendidikan tinggi.

Pendidikan karakter di perguruan tinggi bertujuan untuk meningkatkan mutu penyelenggaraan dan hasil pendidikan yang mengarah pada pencapaian pembentukan karakter dan akhlak mulia mahasiswa secara utuh, terpadu dan seimbang sesuai stadar kompetensi lulusan. Melalui pendidikan karakter diharapkan mahasiswa mampu secara mandiri meningkatkan dan menggunakan pengetahuannya, mengkaji dan menginternalisasi nilai-nilai karakter sehingga terwujud dalam perilaku sehari-hari. Nilainilai karakter yang diterapkan di perguruan tinggi adalah memilih nilai-nilai inti yang dikembangkan dalam implementasi Pendidikan karakter.

Pembangunan karakter (character building) di dunia kampus, terutama di perguruan tinggi, dilatar belakangi oleh maraknya penyimpangan yang terjadi di ranah publik. Disorientasi nilai maupun disharmonisasi pada tataran kehidupan masyarakat kerap ditemukan. Selain itu ditataran elite, ragam tindakan nirketeladanan dipertontonkan seperti perilaku korupsi. Dari perspektif sosial, budaya malu perlahan-lahan mulai hilang. Belum lagi sikap tak menghargai orang lain hingga timbulnya kekerasan di tengah kehidupan masyarakat. Oleh karena itu, pembangunan karakter ingin mengembalikan paradigma berpikir agar mahasiswa tidak hanya pintar, berpengetahuan, dan unggul, tetapi juga bertanggung jawab dan beretika.

\section{Rumusan Masalah}

Berdasarkan latar belakang masalah di atas, maka rumusan masalah dalam makalah ini adalah sebagai berikut:

a. Apa problematika pendidikan karakter pada pendidikan tinggi ?

b. Apakah perlu pendidikan karakter pada pendidikan tinggi?

c. Bagaimana implementasi pendidikan karakter di pergurun tinggi

\section{B. Landasan Teori}

1. Problematika

\footnotetext{
${ }^{2}$ Thomas Lickona, Mendidik Untuk Membentuk Karakter, Jakarta, Bumi Aksara, 2016, hal. viii
} 
Istilah problem/problematika berasal dari Bahasa Inggris yaitu "problematic" yang artinya persoalan atau masalah. Sedang dalam kamus Bahasa Indonesia, problema berarti hal yang belum dapat dipecahkan; yang menimbulkan permasalahan ${ }^{3}$. Adapun masalah itu sendiri adalah suatu kendala atau persoalan yang harus dipecahkan, dengan kata lain masalah merupakan kesenjangan antara kenyataan dengan suatu yang diharapkan dengan baik, agar tercapai hasil yang maksimal.

Definisi problema/problematika adalah suatu kesenjangan antara harapan dan kenyataan yang diharapkan dapat menyelesaikan atau dapat diperlukan atau dengan kata lain dapat mengurangi kesenjangan itu .

\section{Pendidikan}

Dalam Kamus Besar Bahasa Indonesia, Pendidikan adalah sebuah proses pengubahan sikap dan tata laku seseorang atau kelompok orang dalam usaha mendewasakan manusia melalui upaya pengajaran dan pelatihan. Pendidikan diartikan sebagai sebuah perbuatan atau proses perbuatan untuk memperoleh pengetahuan ${ }^{5}$.

Pendidikan adalah usaha sadar dan terencana untuk mewujudkan suasana belajar dan proses pembelajaran agar peserta didik secara aktif mengembangkan potensi dirinya untuk memiliki kekuatan spiritual keagamaan, pengendalian diri, kepribadian, kecerdasan, akhlak mulia, serta ketrampilan yang diperlukan dirinya, masyarakat, bangsa dan negara (UURI No 20/2003, Pasal 1 ayat 1). Selanjutnya, pada pasal 1 ayat 2 UURI No 20/2003 dinyatakan bahwa pendidikan nasional adalah Pendidikan yang berdasarkan Pancasila dan Undang-Undang Dasar Negara Republik Indonesia Tahun 1945 yang berakar pada nilai-nilai agama, kebudayaan nasional Indonesia, dan tanggap terhadap tuntutan perbuatan zaman.

Pendidikan tidak hanya bermakna sebagai tarbiyah, namun mencakup juga ta'lim dan ta'dib, sebagaimana diajarkan oleh Rasulullah, pendidikan tidak hanya mengacu pada transfer pengetahuan atau ilmu ke otak sebagai sumber intelektualitas, namun juga melibatkan hati (spiritual) dan perilaku (akhlak) ${ }^{6}$

\section{Karakter}

Karakter adalah moralitas, kebenaran, kebaikan, kekuatan, dan sikap seseorang yang ditunjukkan kepada orang lain melalui tindakan. Baik atau buruknya karakter tergambar dalam moralitas yang dimiliki ${ }^{7}$.

Thomas Lickona mengatakan bahwa karakter memiliki tiga bagian yang saling berhubungan; pengetahuan moral, perasaan moral, dan perilaku moral. Karakter yang baik terdiri dari mengetahui hal yang baik, menginginkan hal yang baik, dan melakukan hal yang baik - kebiasaan dalam cara berpikir, kebiasaan dalam hati, dan kebiasaan dalam tindakan. Ketiga hal ini diperlukan untuk mengarahkan suatu kehidupan moral; ketiganya ini membentuk kedewasaan moral. Ketika kita berpikir tentang jenis karakter yang kita inginkan bagi anak-anak kita, sudah jelah bahwa kita menginginkan anakanak kita untuk mampu menilai apa yang benar, sangat peduli tentang apa yang benar, dan kemudian melakukan apa yang mereka yakini itu benar - meskipun berhadapan dengan godaan dari dalam dan tekanan dari luar. ${ }^{8}$

\footnotetext{
${ }^{3}$ Depdikbud, Kamus Besar Bahasa Indonesia, Jakarta, Bulan Bintang, 2002, hal. 276

${ }^{4}$ Syukir, Dasar-dasar Strategi Dakwah Islam, Surabaya, Al-Ikhlas, 1983, hal. 65

${ }^{5}$ Op cit

${ }^{6}$ M.Ainur Rasyid, Hadits-hadits Tarbawi, Yogyakarta, Diva Press, 2017, hal. 11

${ }^{7}$ Muhammad Yaumi, Pendidikan Karakter Landasan Pilar \& Implementasi, Jakarta, Prenada Media Group, 2014, hal. 7

${ }^{8}$ Thomas Lickona, Mendidik Untuk Membentuk Karakter, Jakarta, Bumi Aksara, 2016, hal.82
} 
Muchlas Samani dan Hariyanto mengungkapkan bahwa ada berbagai karakter yang harus dimiliki yang bersumber dari Al-Qur'an dan atau Hadis Nabi Saw, diantaranya adalah: ${ }^{9}$

1) Menjaga harga diri

2) Rajin bekerja mencari rizki

3) Bersilaturahmi, menyambung komunikasi

4) Berkomunikasi dengan baik dan santun, gemar memberi salam

5) Jujur, tidak curang, menepati janji, dan amanah

6) Berbuat adil, tolong menolong, saling mengasihi, dan saling menyayangi

7) Sabar dan optimis

8) Kasih sayang dan hormat pada orang tua, tidak menipu

9) Pemaaf dan dermawan

10) Berempati, berbela rasa sebagai manifestasi kebaikan

11) Berkata benar, tidak berdosta

12) Selalu bersyukur

13) Tidak sombong dan angkuh

14) Berbudi pekerti (akhlak) luhur

15) Berbuat baik dalam segala hal

16) Punya rasa malu dan iman

17) Berkata yang baik atau diam

18) Konsisten, istikamah

19) Teguh hati, tidak berputus asa

20) Bertanggung jawab

21) Cinta damai

\section{Pendidikan Tinggi}

Pendidikan tinggi merupakan jenjang pendidikan setelah pendidikan menengah yang mencakup program pendidikan diploma, sarjana, magister, spesialis dan doktor yang diselenggarakan oleh perguruan tinggi. ${ }^{10}$

Dalam peraturan pemerintah Republik Indonesia Nomor 30 Tahun 1990 tentang perguruan tinggi bahwa pendidikan tinggi adalah pendidikan jenjang yang lebih tinggi dari pada pendidikan menengah di jalur pendidikan sekolah. Perguruan Tinggi merupakan suatu pendidikan yang menjadi terminal akhir bagi seorang yang berpeluang belajar setingginya melalui jalur pendidikan sekolah.

Pendidikan dalam Islam tidak hanya dilaksanakan dalam Batasan waktu tertentu saja, melainkan dilakukan sepanjang usia (long life education). Islam memotivasi pemeluknya untuk selalu meningkatkan kualitas keilmuan dan pengetahuan. Tua atau muda, pria atau wanita, miskin atau kaya mendapatkan porsi sama dalam pandangan Islam dalam kewajiban untuk menuntut ilmu (pendidikan) bukan hanya pengetahuan yang terkait urusan ukhrowi saja yang ditekankan oleh Islam, melainkan pengetahuan yang terkait dengan urusan duniawi juga. Karena tidak mungkin manusia mencapai kebahagiaan hari kelak tanpa melalui jalan kehidupan dunia ini.

\section{Pembahasan}

1. Problematika Pendidikan Karakter

\footnotetext{
${ }^{9}$ Muchlas Samani dan Hariyanto, Pendidikan Karakter, Bandung, Remaja Rosdakarya, 2016, hal. 79

${ }^{10}$ UU No. 20 Tentang Sistem Pendidikan Nasional, 2003, hal. 20
} 
Undang Undang No. 20 Tahun 2003 tentang Sistem Pendidikan Nasional, pasal 3 menyebutkan, pendidikan nasional berfungsi mengembangkan kemampuan dan membentuk karakter serta peradaban bangsa yang bermartabat dalam rangka mencerdaskan kehidupan bangsa. ${ }^{11}$ Pendidikan nasional bertujuan untuk berkembangnya potensi peserta didik agar menjadi manusia yang beriman dan bertakwa kepada Tuhan yang Maha Esa, berahlak mulia, sehat, berilmu, cerdas, kreatif, mandiri, menjadi warga negara yang baik serta bertanggung jawab . Untuk mencapai tujuan pendidikan nasional maka setiap jenjang pendidikan harus diselenggarakan pendidikan budaya dan karakter secara terprogram dan sistematis, dengan mengintegrasikan muatan nilai-nilai budaya dan karakter bangsa, untuk menghasilkan insan Indonesia yang cerdas dan kompetitif.

Pembangunan karakter yang merupakan upaya perwujudan amanat Pancasila dan Pembukaan UUD 1945 dilatarbelakangi oleh realita permasalahan kebangsaan yang berkembang saat ini, seperti: disorientasi dan belum dihayatinya nilai-nilai Pancasila; keterbatasan perangkat kebijakan terpadu dalam mewujudkan nilai-nilai Pancasila; bergesernya nilai etika dalam kehidupan berbangsa dan bernegara; memudarnya kesadaran terhadap nilai-nilai budaya bangsa; ancaman disintegrasi bangsa; dan melemahnya kemandirian bangsa. ${ }^{12}$ Untuk mendukung perwujudan cita-cita pembangunan karakter sebagaimana diamanatkan dalam Pancasila dan Pembukaan UUD 1945 serta mengatasi permasalahan kebangsaan saat ini, maka Pemerintah menjadikan pembangunan karakter sebagai salah satu program prioritas pembangunan nasional. Semangat itu secara implisit ditegaskan dalam Rencana Pembangunan Jangka Panjang Nasional (RPJPN) tahun 20052025, di mana pendidikan karakter ditempatkan sebagai landasan untuk mewujudkan visi pembangunan nasional, yaitu "Mewujudkan masyarakat berakhlak mulia, bermoral, beretika, berbudaya, dan beradab berdasarkan falsafah Pancasila."

Terkait dengan upaya mewujudkan pembangunan nasional, pendidikan karakter pada intinya bertujuan membentuk bangsa yang tangguh, kompetitif, berakhlak mulia, bermoral, bertoleran, bergotong royong, berjiwa patriotic, berkembang dinamis, berorientasi ilmu pengetahuan dan teknologi yang semuanya dijiwai oleh iman dan takwa kepada Tuhan Yang Maha Esa berdasarkan Pancasila. ${ }^{13}$ Pendidikan karakter disebutkan sebagai pendidikan nilai, pendidikan budi pekerti, pendidikan moral, pendidikan watak yang bertujuan mengembangkan kemampuan seluruh warga sekolah untuk memberikan keputusan baik-buruk, keteladanan, memelihara apa yang baik dan mewujudkan kebaikan itu dalam kehidupan sehari-hari dengan sepenuh hati.

Menurut Sutarjo Adisusilo, karakter menjadi identitas, menjadi ciri, menjadi sifat yang tetap. Jadi karakter adalah seperangkat nilai yang telah menjadi kebiasaan hidup sehingga menjadi sifat tetap dalam diri seseorang, misalnya kerja keras, pantang menyerah, jujur, sederhana, dan lain-lain. ${ }^{14}$ Dengan karakter itulah kualitas seorang pribadi diukur. Lebih lanjut dia mengatakan bahwa ada empat ciri dasar pendidikan karakter. Pertama, keteraturan interior di mana setiap tindakan diukur berdasarkan seperangkat nilai. Nilai menjadi pedoman normatif setiap tindakan. Kedua, koherensi yang memberi keberanian, yang membuat seseorang teguh pada prinsip, tidak mudah terombang-ambing pada situasi. Koherensi ini merupakan dasar yang membangun rasa percaya satu sama lain, tanpa koherensi maka kredibilitas seseorang akan runtuh. Ketiga, otonomi maksudnya seseorang menginternalisasi nilai-nilai dari luar sehingga menjadi

\footnotetext{
${ }^{11}$ Sutarjo Adisusilo, Pembelajaran Nilai-Karakter, Jakarta, RajaGrafindo Persada, 2014, hal. 76

12 Kemdiknas, Panduan Pelaksanaan Pendidikan Karakter, Jakarta, Kemdiknas, 2011, hal. 5

${ }_{13}$ Muchlas Samani \& Hariyanto, Pendidikan Karakter, Bandung, Remaja Rosdakarya, 2016, hal.52

${ }^{14}$ Sutarjo Adisusilo, Pembelajaran Nilai-Karakter, Jakarta, Raja Grafindo Persada, 2014, hal. 78
} 
nilai-nilai pribadi, menjadi sifat yang melekat melalui keputusan bebas tanpa paksaan dari orang lain. Keempat, keteguhan dan kesetiaan. Keteguhan merupakan daya tahan seseorang guna mengingini apa yang dipandang baik, dan kesetiaan merupakan dasar bagi penghormatan atas komitmen yang dipilih.

Atas dasar apa yang telah diungkapkan di atas, pendidikan karakter bukan hanya sekedar mengajarkan mana yang benar dan mana yang salah. Lebih dari itu, pendidikan karakter adalah usaha menanamkan kebiasaan-kebiasaan yang baik (habituation) sehingga peserta didik mampu bersikap dan bertindak berdasarkan nilai-nilai yang telah menjadi kepribadiannya. Nilai-nilai tersebut harus ditumbuhkembangkan pada setiap peserta didik hingga berkembang menjadi budaya sekolah (school culture).

Pendidikan karakter bersumber dari Agama, Pancasila, budaya, dan tujuan pendidikan nasional, yaitu: religius, jujur, toleransi, disiplin, kerja keras, kreatif, mandiri, demokratis, rasa ingin tahu, semangat kebangsaan, cinta tanah air, menghargai prestasi, bersahabat/komunikatif cinta damai, gemar membaca, peduli lingkungan, peduli sosial, dan tanggung jawab. ${ }^{15}$

Adapun problematika Pendidikan Karakter di Indonesia diantaranya adalah $:^{16}$

Tenaga Pendidik

Pendidikan karakter di Indonesia pada umumnya dititikberatkan pada guru pendidikan Agama dan Bimbingan Konseling. Rencana pelaksanaan pembelajaran hanyalah formalitas dalam pelaksanaan kegiatan pembelajaran dan juga RPP menjadi beban kerja yang lebih tinggi seorang guru. RPP dipersiapkan dengan baik hanya untuk atasan tahu bahwa mereka mengajar sesuai dengan RPP, tetapi dalam eksekusinya jauh berbeda dari rencana. Akibatnya tidak ada efek atau pengaruh terhadap siswa melalui apa yang disampaikan oleh guru. Belum lagi masalah dari guru Pendidikan Agama Islam dan guru Bimbingan Konseling. Jika peran guru Pendidikan Agama Islam sebatas menerapkan teori dan guru Bimbingan Konseling sebatas menangani masalah tanpa adanya suatu tindakan follow up, dipastikan bahwa kehadiran mereka juga hanyalah sebuah formalitas.

Orang Tua

Kemajuan Ilmu Pengetahuan dan Teknologi punya dampak yang sangat besar bagi pembentukan karakter siswa. Dengan adanya zaman modernisasi ini, kehidupan remaja bahkan anak-anak sangat memprihatinkan. Pendidikan karakter merupakan pengaruh yang diberikan oleh seseorang dalam pembentukan perilaku baik itu di sekolah, di rumah maupun lingkungan sosial masyarakat. Pendidikan karakter di kampus adalah segala sesuatu yang dilakukan oleh seorang dosen, mampu mempengaruhi karakter mahasiswa. Dosen turut serta mengembangkan karakter mahasiswa. Hal ini mencakup banyak hal tentang keteladanan seorang dosen baik itu perilaku, cara berbicara, hidup bertoleransi, berintegritas dan lain-lain yang berkaitan dengan karakter.

Pola asuh orang tua atau pendidik yang diapresiasi anak sebagai undangan, bantuan, bimbingan, dan dorongan untuk membentuknya mengembangkan diri sebagai pribadi yang berkarakter adalah orang tua atau pendidik yang mampu memancarkan kewibawaan pada anak. Pendidik atau orang tua yang mampu berbuat demikian, dia senantiasa

\footnotetext{
${ }^{15}$ Sartono, Pengintegrasian Pendidikan Karakter dalam Pengembangan Kurikulum Tingkat Satuan Pendidikan, Makalah Disertasi, 2011, hal. 9

${ }^{16}$ Kompasiana.com.mas 10 Januari 2019
} 
menampilkan perilaku yang konsisten antara bahasa lisan dan perbuatannya, menerima anak apa adanya dan menghargai yang dimiliki serta perilaku anak. ${ }^{17}$

Terbatasnya nilai-nilai karakter yang terintegrasi dalam pelaksanaan pembelajaran dan kegiatan ekstrakurikuler paling tidak disebabkan oleh dua faktor utama. Pertama, ketiadaan mata pelajaran/kuliah pendidikan karakter pendidikan secara tersendiri. Hal ini telah menyebabkan materi (bahan) ajar yang tersedia tidak dapat seluruhnya dikembangkan dalam mata pelajaran tertentu, sehingga pengetahuan tentang pendidikan karakter tidak dicerna secara komprehensif oleh peserta didik. Begitu pula sikap dan perilaku peserta didik belum bisa mencerminkan nilai-nilai karakter yang diharapkan. Kedua, kesulitan pendidik dalam memahami strategi pengembangan bahan ajar yang mengintegrasikan nilai-nilai karakter ke dalam setiap aktivitas pembelajaran. ${ }^{18}$

\section{Strategi Pelaksanaan Pendidikan Karakter}

Strategi dapat dimaknai dalam kaitannya dengan kurikulum, strategi dalam kaitannya dengan model tokoh, serta strategi dalam kaitannya dengan metodologi. Dalam kaitannya dengan kurikulum, strategi yang umum dilaksanakan adalah mengintegrasikan pendidikan karakter dalam bahan ajar. Strategi terkait dengan adanya model tokoh yang sering dilakukan di negara-negara maju adalah bahwa seluruh tenaga pendidik dan tenaga kependidikan harus mampu menjadi model teladan yang baik (uswah hasanah). Dalam kaitannya dengan metodologi, strategi yang umum diimplementasikan pada pelaksanaan Pendidikan karakter di negara-negara barat adalah strtegi pemanduan (cheerleading), pujian dan hadiah (praise-and reward), definisikan dan latihan (define-and-drill), penegakan disiplin (forced-formality), dan juga perangai bulan ini (traits of the month) ${ }^{19}$

Desain induk Pendidikan karakter yang dirancang Kementrian Pendidikan Nasional (2010) strategi pengembangan Pendidikan karakter yang akan diterapkan di Indonesia antara lain melalui transformasi budaya sekolah (school culture) dan habituasi melalui kegiatan ekstrakurikuler. Strategi habituasi Pendidikan karakter melalui budaya sekolah ini, agaknya sejalan dengan pemikiran Berkowitz. Elkind dan Sweet (2004) mengutip Berkowitz menulis: "Effective character education is nota adding a program or set of programs to a school. Rather it is a transformation of the culture and life of the school." Jadi menurut para ahli tersebut, implementasi pendidikan karakter melalui transformasi budaya dan perikehidupan sekolah, dirasakan lebih efektif dari pada mengubah kurikulum dengan menambahkan materi Pendidikan karakter ke dalam muatan kurukulum. ${ }^{20}$

Ada tiga pendekatan pembinaan yaitu Cognitive Moral Development, Affective Moral Development, dan Behavior Moral Development.(masrukhiunnes.wordpress.com, 2015).

Pertama, perlu dilakukan upaya perubahan struktur kognisi terlebih dahulu agar para mahasiswa memahami akan arti pentingnya tata nilai. Menurut pendekatan Cognitive Moral Development, dengan diketahuinya arti pentingnya tata nilai oleh para mahasiswa, diharapkan akan tumbuh kesadaran dan kesiapan untuk menerima tata nilai tersebut

\footnotetext{
${ }^{17}$ Moch, Shohib, Pola Asuh Orang Tua Dalam Membantu Anak Mengembangkan Disiplin Diri, Jakarta, Rineka Cipta, 2014, hal. 207

${ }^{18}$ Muhammad Yaumi, Pendidikan Karakter Landasan, Pilar \& Implementasi, Jakarta, Prenadamedia Group, 2014, hal. 131

${ }^{19}$ Muchlas Samani \& Hariyanto, Konsep dan Model Pendidikan Karakter, Bandung, Remaja Rosdakarya, 2016, hal. 144

${ }^{20}$ Ibid 146
} 
menjadi miliknya sendiri (internalisasi nilai). Kesadaran dan internalisasi nilai yang berawal dari pemahaman akan tata nilai tersebut (struktur kognisi) akan memiliki kekuatan yang otentik, sebagai buah dari proses pembelajarannya (learned behavior). Maksudnya kajian pendidikan karakter pada seluruh mata kuliah, sangat tepat untuk melakukan pembinaan collective consciousness, pada kegiatan-kegiatan formal perkuliahan.

Dengan pendekatan Cognitive Moral Development ini maka internalisasi nilai dilakukan melalui dialog yang efektif antara potensi piker peserta didik dengan tata nilai yang disajikan oleh warga kampus.

Selain upaya character building melalui perubahan struktur kognisi, tidak kalah pentingnya adalah melalui pendekatan intuisi. Pendekatan ini dilakukan dengan cara membawa imajinasi dan suasana hati para mahasiswa pada heroism tata nilai kampus. Hal inilah yang ditekankan oleh pendekatan Affective Moral Development, yaitu menanamkan nilai melalui aras afektif, berupa sentuhan-sentuhan perasaan, imajinasi, dan intuisi. Proses pembinaan afektif ini membutuhkan strategi tersendiri yang berbeda dengan proses-proses pembinaan kognitif. Para pimpinan dan para dosen dituntut untuk mempunyai kepiawian dalam mengelola strategi pendekatan yang dilakukannya. Metode-metode out bond, games, perkuliahan di luar kelas, dan sejenisnya merupakan aplikasi dari pendekatan ini.

Pendekatan Behavior Moral Development memandang bahwa internalisasi nilai dilakukan melalui pembiasaan. Kendatipun pendekatan ini berawal mula dari percobaan yang dilakukan oleh Ivan Pavlov pada seekor binatang, akan tetapi pendekatan ini sangat relevan dengan upaya penanaman nilai. Seorang mahasiswa yang dibiasakan tertib dan berperilaku baik dalam kehidupan sehari-harinya, pada akhirnya akan terbiasa melakukan hal-hal tersebut. Pada gilirannya nanti kebiasaan-kebiasaan yang dilakukannya tersebut akan mengendap menjadi tata nilai milik dirinya sendiri. Mana kala mereka melakukan suatu tindakan di luar kebiasaannya, mereka akan merasa bersalah. Pembiasaan sebagai sebuah metode dalam mananamkan nilai tetap memiliki efektifitas yang tinggi, apalagi jika diikuti dengan adanya reward and punishment, dalam arti yang luas. ${ }^{21}$

Ketiga pendekatan pembinaan nilai tersebut akan memiliki efektifitas tinggi ketika dilakukan secara simultan. Artinya pembinaan karakter dilakukan secara komprehensif, meliputi perubahan struktur kognisi, sentuhan-sentuhan emosional, dan penciptaan lingkungan yang kondusif.

Lingkungan kampus sebagai institusi pengawal character building para mahasiswa, memiliki potensi-potensi yang akan berkontribusi pada proses-prosesnya, sehingga dibutuhkan kebersamaan secara sinergis dalam pembinaannya, dari seluruh warga kampus.

\section{Tolak Ukur Keberhasilan Pendidikan Karakter}

Pendidikan karakter bukan sekedar mengajarkan mana yang benar dan mana yang salah. Lebih dari itu, Pendidikan karakter menanamkan kebiasaan (habituation) tentang hal mana yang baik sehingga peserta didik menjadi paham (kognitif) tentang mana yang benar dan salah, mampu merasakan (afektif) nilai yang baik dan biasa melakukannya (psikomotor). Karakter yang terasa demikian memiliki tiga bagian yang saling berhubungan: pengetahuan moral, perasaan moral, dan perilaku moral. Karakter yang baik terdiri dari mengetahui hal yang baik, menginginkan hal yang baik, dan melakukan hal

${ }^{21}$ Masrukhiunnes.wordpress.com, 2015 
yang baik-kebiasaan dalam cara berpikir, kebiasaan dalam hati, dan kebiasaan dalam tindakan. ${ }^{22}$

Dalam desain induk pendidikan karakter antara lain diutarakan bahwa secara substantif karakter terdiri atas 3 (tiga) nilai operatif (operative value), nilai-nilai dalam tindakan, atau tiga unjuk perilaku yang satu sama lain saling berkaitan dan terdiri atas pengetahuan tentang moral (moral knowing, aspek kognitif), perasaan berlandaskan moral (moral feeling, aspek afektif), dan perilaku berlandaskan moral (moral behavior, aspek psikomotor). Karakter yang baik (good Character) terdiri atas proses-proses yang meliputi, tahu mana yang baik (knowing the good), keinginan melakukan yang baik (desiring the good), dan melakukan yang baik (doing the good). Kecuali itu, karakter yang baik juga harus ditunjang oleh kebiasaan piker (habit of the mind), kebiasaan kalbu (habit of the heart), dan kebiasaan tindakan (habit of action) ${ }^{23}$

Agar pelaksanaan pendidikan karakter berjalan efektif, Lickona telah mengembangkan 11 (sebelas) prinsip untuk pendidikan karakter yang efektif, yaitu: ${ }^{24}$

1) Pendidikan karakter harus mempromosikan nilai-niali etik inti (ethical core values) sebagai landasan bagi pembentukan karakter yang baik.

2) Karakter harus dipahami secara komprehensif termasuk dalam pemikiran, perasaan, dan perilaku.

3) Pendidikan karakter yang efektif memerlukan pendekatan yang sungguh-sungguh dan proaktif serta mempromosikan nilai-nilai inti pada semua fase kehidupan sekolah/kampus.

4) Sekolah/kampus harus menjadi komunitas yang peduli

5) Menyediakan peluang bagi para siswa untuk melakukan tindakan bermoral

6) Pendidikan karakter yang efektif harus dilengkapi dengan kurikulum akademis yang bermakna dan menantang, yang menghargai semua pembelajar dan membantu mereka untuk mencapai sukses.

7) Pendidikan karakter harus secara nyata berupaya mengembangkan motivasi pribadi siswa.

8) Seluruh staf harus menjadi komunitas belajar dan komunitas moral yang semuanya saling berbagi tanggung jawab bagi berlangsungnya pendidikan karakter, dan berupaya untuk mengembangkan nilai-nilai inti yang sama yang menjadi panduan pendidikan karakter bagi para siswa.

9) Implementasi pendidikan karakter membutuhkan kepemimpinan moral yang diperlukan bagi staf maupun siswa.

10) Sekolah harus merekrut orang tua dan anggota masyarakat sebagai partner penuh dalam upaya pembangunan karakter.

11) Evaluasi terhadap Pendidikan karakter harus juga menilai karakter sekolah, menilai fungsi staf sekolah sebagai pendidik karakter, sampai pada penilaian terhadap bagaimana cara para siswa memanifestasikan karakter yang baik.

Melinda dan Berkowitz (2005) mengungkapkan beberapa kondisi di sekolah yang bersifat non kurikulum yang mendukung keberhasilan implementasi pendidikan karakter yaitu $:^{25}$

\footnotetext{
22 Thomas Lickona, Mendidik Untuk Membentuk Karakter, Jakarta, Bumi Aksara, 2016, hal. 82

${ }^{23}$ Muchlas Samani \& hariyanto, Konsep dan Model Pendidikan Karakter, Bandung, Remaja Rosdakarya, 2016, hal $49-50$

${ }^{24}$ Ibid 168

${ }^{25}$ Melinda dan Berkowitz, Leadership For Students Activities, Oktober 2005, vol 34, no 2
} 
1) Budaya kampus dan praktik-praktik interpersonal yang menjamin bahwa mahasiswa diperlakukan dengan perhatian dan hormat.

2) Dosen, staf menjadi model karakter yang baik bagi mahasiswa, menghidupkan nilainilai dalam interaksi keseharian dengan mahasiswa.

3) Memberikan kesempatan pada mahasiswa memiliki otonomi dan pengaruh dalam pengelolaan perguruan tinggi seperti memberikan wadah untuk menampung aspirasi mahasiswa.

4) Memberikan kesempatan mahasiswa untuk mencari pemecahan masalah isu-isu moral.

5) Sharing visi dan sense of collectivity and responsibility.

6) Social skill training artinya kampus menyelenggarakan pelatihan bagi mahasiswa yang tujuannya agar mahasiswa dapat melakukan penyesuaian jangka Panjang dengan memperkuat ketrampilan pemecahan masalah interpersonal.

7) Memberi kesempatan lebih pada mahasiswa untuk berpartisipasi dalam kegiatan pelayanan masyarakat oleh kampus yang bisa menaikkan perilaku moral.

\section{Implementasi Pendidikan Karakter di Perguruan Tinggi}

Perguruan tinggi, menurut Flexner (dalam Syukri 2009) merupakan tempat pencarian ilmu pengetahuan, pemecahan berbagai masalah, tempat mengkritisi karya-karya yang dihasilkan, dan sebagai pusat pelatihan manusia. Senada dengan Flexner, Syukri (2009) menyatakan dunia perguruan tinggi merupakan tempat menyemai, mendidik dan melatih mahasiswa agar menjadi mahasiswa yang memiliki daya nalar tinggi, analisis tajam dan luas. Sayangnya perguruan tinggi kurang memberikan porsi pada pembentuka karakter mahasiswa. Bahkan Arthur (dalam Syukri, 2009) menyatakan jika perguruan tinggi menjanjikan pembentukan dan pengembangan karakter mahasiswa seperti yang terjadi di Inggris, semua itu hanya retorika institusi universitas modern. Sementara itu, menurut Syukri (2009) masyarakat Indonesia masih menaruh harapan pada perguruan tinggi sebagai tempat latihan dan pendidikan putra putrinya menjadi kaum intelektual yang memiliki ilmu tinggi dan perilaku terpuji. Ironisnya taka da perguruan tinggi yang menjamin lulusannya memiliki moral etika yang baik. ${ }^{26}$

Mengacu pada Kebijakan Nasional Pendidikan Karakter Bangsa (2010), Kementrian Pendidikan Nasional telah menyusun Desain Induk Pendidikan Karakter 2010. Isinya mencakup antara lain kerangka dasar, pendekatan, dan strategi implementasi pendidikan karakter. Konfigurasi karakter ditetapkan berdasarkan empat proses psikososial, yaitu: (1) Olah pikir, nilai-nilai yang terdapat di dalam olah piker ini adalah cerdas, kritis, kreatif, inovatif, ingin tahu, berpikir terbuka, produktif, berorientasi ipteks, dan reflektif. (2) Olah hati, yang berasal dari olah ini adalah jujur, beriman dan bertakwa, amanah, adil, bertanggung jawab, berempati, berani mengambil resiko, rela berkorban, dan berjiwa patriotic. (3) Olah raga, Tangguh, bersih dan sehat, disiplin, sportif, andal, berdaya tahan, bersahabat, kooperatif, kompetitif, ceria. (4) Olah rasa/karsa, peduli, ramah, santun, rapi, nyaman, saling menghargai, toleran, suka menolong, gotong royong, nasionalis/kosmopolit, mengutamakan kepentingan umum, bangga menggunakan Bahasa dan produk Indonesia,, dinamis, kerja keras, beretos kerja, dan gigih. ${ }^{27}$

\footnotetext{
${ }^{26}$ Syukri, Peran Pendidikan di Perguruan Tinggi terhadap Perubahan Perilaku Kaum Intelektual, Jurnal IImiah Kreatif, 2009, Vol 6 No 1

${ }^{27}$ Kementrian Pendidikan Nasional, 2010, hal. 9
} 
Pendidikan karakter di lingkup satuan Pendidikan perguruan tinggi dilaksanakan melalui tridharma perguruan tinggi, budaya organisasi, kegiatan kemahasiswaan, dan kegiatan keseharian (Tim Pendidikan Karakter Ditjen Dikti,2010). Penjelasan dari setiap aspek pendidikan sebagai berikut:

Tridharma Perguruan Tinggi: Pengintegrasian nilai-nilai utama ke dalam kegiatan Pendidikan, penelitian, serta publikasi ilmiah, dan pengabdian kepada masyarakat;

Budaya organisasi: pembiasaan dalam kepemimpinan dan pengelolaan perguruan tinggi;

Kegiatan kemahasiswaan, antara lain: pramuka, olah raga, karya tulis, seni;

Kegiatan keseharian: Penerapan pembiasaan dalam kehidupan sehari-hari di lingkungan kampus, asrama/pondokan/keluarga, dan masyarakat.

Untuk mewujudkan budaya perguruan tinggi diperlukan karakter individu, diperlukan pengembangan diri secara holistic, yang bersumber pada olah hati, olah piker, olah raga, dan olah karsa, seperti yang telah dikemukakan dari konfigurasi nilai yang terdapat dalam ranah olah hati, olah piker, olah raga, dan olah rasa/karsa masing-masing diambil satu nilai sebagai nilai-nilai utama karakter yang dikembangkan secara nasional, termasuk dilingkungan Dikti. Karakter yang dimaksud adalah: Jujur, Cerdas, Tangguh, Peduli (Jurdastangli)

Disisi lain, misi perguruan tinggi adalah pengajaran, penelitian dan aplikasi ilmu pengetahuan (Arthur, dalam Syukri 2009), sehingga secara eksplisit pembentukan karakter dianggap bukan merupakan tugas perguruan tinggi. Oleh karena itu implementasi pendidikan karakter di perguruan tinggi akan menemui tantangan tersendiri. Schwartz (2000) menyatakan beberapa hal yang menyebabkan pendidikan karakter di perguruan tinggi akan menemui kendala karena adanya pendapat yang keliru yaitu :

1) Karakter seseorang adalah terbentuk sebelum masuk ke perguruan tinggi dan merupakan tanggung jawab orang tua untuk membentuk karakter anaknya.

2) Perguruan tinggi, khususnya dosen, tidak memiliki kepentingan dengan pembentukan karakter, karena mereka direkrut bukan untuk melakukan hal tersebut.

3) Karakter merupakan istilah yang mengacu pada agama atau idiologi konservatif tertentu, sementara itu perguruan tinggi di barat secara umum melepaskan diri dari agama atau idiologi tertentu.

Keengganan [perguruan tinggi di barat seperti Inggris dan Amerika Serikat, mengurus masalah moral antara lain karena masalah moral merupakan wilayah pribadi dan mereka dipengaruhi oleh idiologi liberal yang telah menjadi gaya hidup. Selain itu, ada empat alasan perguruan tinggi, khususnya di Inggris yang tidak menaruh perhatian pada pembentukan moral mahasiswa : (1) takut dengan tuntutan berbagai macam karakter dan perilaku mahasiswa untuk mendapatkan pembinaan, (2) menjalankan pendidikan sesuai dengan kebijakan politik pemerintah, (3) mahasiswa diarahkan menjadi warga negara yang demokratis, (4) perguruan tinggi mengembangkan karakter sesuai dengan tuntutan pasar dan jaringan.$^{28}$

Uraian di atas menggambarkan bahwa meskipun pendidikan karakter di perguruan tinggi bisa melengkapi puzzle karakter yang belum terbentuk pada tingkatan pendidikan sebelumnya, namun hal tersebut tidak akan berjalan dengan mudah. Schwartz (2000) juga menyatakan hanya ada relatif sedikit institusi, biasanya institusi kecil yang berafiliasi agama atau berjuang untuk menginspirasi, yang memiliki

\footnotetext{
${ }^{28}$ Syukri, Peran Pendidikan di Perguruan Tinggi terhadap Perubahan Perilaku Kaum Intelektual, Jurnal IImiah Kreatif, 2009, Vol 6 No 1,
} 
komitmen luas dan komprehensif terhadap perkembangan karakter dalam semua dimensi kehidupan perguruan tinggi.

Meskipun demikian, perguruan tinggi tidak boleh lepas tangan atau lepas tanggung jawab dengan alasan apapun termasuk menganggap bahwa karakter adalah terbentuk sebelum mahasiswa masuk perguruan tinggi, merupakan tanggung jawab orang tua dan institusi Pendidikan di tingkat bawahnya, apalagi dengan alasan beban berat menghasilkan lulusan sesuai tuntutan pasar. Sebagai institusi pencetak sumber daya manusia yang akan menjadi penyokong utama kualitas sumber daya manusia Indonesia, perguruan tinggi memikul tanggung jawab mewujudkan amanat UU sistem Pendidikan nasional tahun 2003 dan PP no 17 tahun 2010 tentang perguruan tinggi. Apalagi jika mengingat data dari Badan Perencana Pembangunan Nasional (Bappenas) mengklaim indeks pembagunan manusia (IPM), alias kualitas sumber daya manusia (SDM) Indonesia pada 2011 yang masih menempatkan Indonesia di bawah Malaysia (61), Singapura (26), dan Brunei Darussalam (33) (neraca.co.id, 17 April 2012), dan juga kerusakan moral bangsa ini telah membawa perjalanan bangsa ini mencapai masyarakat madani menjadi terseok-seok.

Jika pendidikan karakter sudah ada atau dilaksanakan pada tingkat pendidikan sebelumnya, maka pendidikan karakter di perguruan tinggi akan menjadi pelengkap, untuk rebuild dan reshape, mengingat karakter bukanlah suatu hal yang menetap dan sama sekali tidak bisa berubah atau baik ke arah yang lebih baik atau malah ke arah kemerosotan karena pengaruh lingkungan. Selain itu, ketiadaan koordinasi mengenai karakter apa yang akan dibentuk pada tingkat Pendidikan dasar, menengah pertama, maupun menengah atas, menjadikan kedudukan perguruan tinggi sebagai institusi pendidikan yang paling akhir untuk melengkapi puzzle karakter yang belum ada dan membentuk karakter menjadi "bangunan moral yang sudah jadi dan kokoh" pada mahasiswa. Dengan demikian lulusan perguruan tinggi akan menjadi manusia dengan kualitas ganda baik kualitas professional sesuai keilmuannya dan kualitas moral yang tinggi, sehingga dapat berkiprah sebagai warga negara yang baik sesuai bidang pekerjaannya.

Untuk mewujudkan pembentukan karakter Schwartz (2000) menyatakan universitas, baik yang berlatarbelakang religious maupun yang sekuler, dapat menggunakan kekuatan kurikulumnya, khususnya efek baiknya, untuk membentuk pemikiran tetapi juga karakternya. Kurikulum ini tidak saja membentuk intellectual habits namun juga moral habits mahasiswa. ${ }^{29}$

Perguruan tinggi memiliki pilihan dalam mengajarkan pembentukan karakter yaitu dapat mengintegrasikannya secara alami dengan kurikulum standar maupun mengajarkan beriringan dengan kurikulum standar. Dibandingkan dengan menambahkan serangkaian pertemuan terpisah pada kurikulum yang sesungguhnya sudah padat, pilihan yang mudah adalah mengintegrasikan dengan mata pelajaran/ mata kuliah pada semua kelas oleh semua pendidik (Stiff-William, 2010). Hal ini sesuai dengan salah satu pilar pendidikan yang digariskan UNESCO dalam memberikan rambu-rambu menyusun kurikulum untuk pengembangan kepribadian mahasiswa yaitu learning to be (belajar memahami diri sendiri). Perguruan tinggi di Indonesia menggunakan istilah khusus berkaitan dengan hal tersebut yaitu Mata Kuliah Pengembangan Kepribadian. ${ }^{30}$

\footnotetext{
${ }^{29}$ Schwarts, The Chronicle of Higher Education, 2000, Vol 46 No 40

${ }^{30}$ Syukri, Peran Pendidikan di Perguruan Tinggi Terhadap Perubahan Perilaku Kaum Intelektual, Jurnal Ilmiah Kreatif 2009, Vol 6 No 1
}

68 ITahdzib AkhIaq No V/1/2020 
Dengan demikian, jika perguruan tinggi tidak menyusun program Pendidikan karakter tersendiri namun mengintegrasikannya kedalam kurikulum standar yang sudah ada, maka yang perlu dilakukan adalah meninjau kambali muatan mata kuliah pengembangan kepribadian dan mengembalikannya kea rah pembentukan karakter sesuai amanat Undang-Undang Sisdiknas. Tentu saja hal ini membawa konsekuensi cara pengajaran yang berbeda, dan cara pemberian nilai yang berbeda, tidak lagi mengevaluasi penguasaan teori atau kemampuan kognitif mahasiswa namun lebih jauh mengevaluasi implementasi karakter atau nilai-nilai luhur. Adapun bentuk evaluasi maupun formula penilaiannya dapat didiskusikan lebih lanjut dengan dosen-dosen sehingga kepemilikan program ini menjadi ada pada seluruh civitas akademika.

Selain melalui mata kuliah pengembangan kepribadian, semua dosen pada semua mata kuliah hendaknya menjadi figure yang mempraktekkan pembentukan karakter ini dalam semua aktivitas di kelas maupun di luar kelas. Jika hal ini bisa dilakukan maka semua lingkungan di kampus, baik di kelas, luar kelas maupun kantor administrative akan mencerminkan lingkungan yang mendukung pembentukan karakter.

Beberapa kondisi di luar kurikulum yang perlu diperhatikan perguruan tinggi karena hal-hal tersebut mendukung suksesnya implementasi pendidikan karakter menurut Melinda dan Berkowitz (2005) adalah : (1) budaya kampus dan praktik-praktik interpersonal yang menjamin bahwa mahasiswa diperlakukan dengan perhatian dan hormat, (2) Dosen, staf menjadi model karakter yang baik, bagi mahasiswa, menghidupkan nilai-nilai dalam interaksi keseharian dengan mahasiswa, (3) memberikan kesempatan pada mahasiswa memiliki otonomi dan pengaruh dalam pengelolaan perguruan tinggi seperti memberikan wadah untuk menampung aspirasi mahasiswa, (4) memberikan kesempatan mahasiswa untuk reflesi, berdebat maupun berkolaborasi mencari pemecahan masalah isu-isu moral, (5) sharing visi dan sense of collectivity and responsibility, (6) social skill training artinya kampus menyelenggarakan pelatihan bagi mahasiswa yang tujuannya agar mahasiswa dapat melakukan penyesuaian jangka Panjang dengan memperkuat ketrampilan pemecahan masalah interpersonal, (7) memberi kesempatan lebih pada mahasiswa untuk berpartisipasi dalam kegiatan pelayanan masyarakat oleh kampus yang bisa menaikkan perilaku moral. ${ }^{31}$

Dengan demikian dosen maupun staf administrative akan menemui tantangan tersendiri karena mereka akan menjadi pribadi yang juga berupaya menjadi model yang baik bagi mahasiswa. Schwartz (2000) menyebutnya dengan istilah mendorong dan mengispirasi agar mahasiswa mengembangkan moral yang baik dan trait, yang akan membuat mereka menjadi orang dewasa yang matang dan bertanggung jawab.

Hal yang tak kalah penting menurut Syukri (2009) adalah kejujuran perguruan tinggi akan ketidakmampuannya untuk berdiri sendiri menyelenggarakan pendidikan karakter. Perguruan tinggi harus mengakui bahwa kerjasama dengan stake holder, dalam hal ini orang tua dan masyarakat sekitar adalah penting. Satu hal yang bisa dilakukan, menurut Melinda dan Berkowitz (2005) adalah dengan memberikan newsletter mengenai pembentukan karakter dalam keluarga dan masyarakat.

Meskipun berbagai strategi dan pendekatan yang digunakan mungkin berbeda, namun tujuannya adalah sama yaitu mendorong dan menginspirasi mahasiswa untuk mengembangkan dan menerapkan moralnya sendiri ketika berada dalam tekanan lingkungan.

${ }^{31}$ Melinda, Berkowitz, Leadership For Students Activities, Oktober 2005, Vol 34, No 2 


\section{Implementasi dalam Perkuliahan}

Secara akademik, gagasan untuk melaksanakan pendidikan karakter memberi inspirasi baru bagi para ilmuwan pendidikan, akademisi, dan praktisi pendidikan di Indonesia untuk menelaah lebih jauh di samping mengkaji secara komprehensif tentang konsep dan teori yang berkenaan dengan pendidikan karakter tersebut. Bahkan sebagian pakar pendidikan telah memasukkan konsep pendidikan karakter dan budaya bangsa sebagai salah satu kajian pada mata kuliah "Isu-isu Kritis dalam Pendidikan." Oleh karena itu, banyak di kalangan maha siswa S-2 dan S-3 yang mulai tertarik untuk melakukan penelitian dan pengembangan (research \& development) model pendidikan karakter dan budaya bangsa. ${ }^{32}$ Secara substantive pendidikan karakter berkenaan dengan pendidikan afektif. Aspek afektif merupakan aspek yang berkenaan dengan apaapa yang terdapat dalam diri peserta didik, sehingga keberadaannya selalu tersembunyi. Dia berkenaan dengan dunia kejiwaan, cita-cita dan rasa, citra serta keyakinan manusia.

Aspek yang keberadaannya tersembunyi dan berada dalam diri peserta didik sangat sulit untuk diketahui dan diukur, apalagi untuk dibina dan diarahkan melalui proses perkuliahan di dalam kelas. Namun demikian, dengan semakin berkembangnya dunia psikologi khususnya yang berkenaan dengan pendidikan melakukan penemuanpenemuan baru mengenai dunia kejiwaan manusia, muncullah tokoh-tokoh pendidikan yang optimis akan pengkajian dan penelaahan akan aspek afektif ini untuk kepentingan pengajaran. Mereka diantaranya adalah Piaget, Kohlbreg, Metcalf, dsb. Mereka berpendapat bahwa keyakinan akan sesuatu yang paling baik hendaknya merupakan hasil belajar (Learned Behavior), sebagai hasil dari proses internalisasi secara nalar dari para siswa terhadap nilai-nilai kebenaran dan Learned Behavior dari Pendidikan karakter pun yang dapat diketahui dan ditelaah hanyalah indikator-indikatornya saja yaitu berupa tingkah laku yang tampak dari luar. ${ }^{33}$

Proses perkuliahan merupakan proses komunikasi yang berkarakteritikkan interaksi edukatif, yaitu komunikasi timbal balik antara dosen dengan mahasiswa dalam mencapai suatu tujuan perkuliahan. Oleh karena itu sumber belajar yang dirancang dengan baik dalam batas tertentu akan dapat merangsang timbulnya semacam dialog internal dalam diri mahasiswa. Dengan kata lain terjadi komunikasi bermakna antara mahasiswa dengan sumber belajar yang dihadapinya.

Dengan tercapainya dialog internal pada diri mahasiswa menjadikan mereka berusaha untuk menangkap pesan dari media tersebut, sehingga telah terjadi proses pembelajaran. Media berhasil membawakan pesan sebagai sumber belajar, apabila kemudian terjadi perubahan pola fikir, tingkah laku atau sikap belajar pada diri siswa. Berkaitan dengan hal tersebut, perencanaan pesan-pesan pembangunan karakter dalam proses perkuliahan sangat diperlukan. Perencanaan dimaksud disesuaikan kejiwaan mahasiswa. Perencanaan yang baik akan menghasilkan proses-proses perkuliahan yang kondusif bagi terjadinya dialog antara peserta didik dengan sumber belajar yang ada, yang pada gilirannya akan tertanam konsep-konsep pendidikan karakter dalam tingkatannya yang sangat sederhana dan konkrit.

Penanaman karakter pada para peserta didik merupakan proses penyesuaian kepribadian yang perlu memperhatikan bermacam-macam prinsip dasar pertumbuhan. Mekanisme penyesuaian tersebut pada dasarnya merupakan sebagian dari usaha kependidikan yang dilakukan oleh keluarga, sekolah, maupun masyarakat, serta

\footnotetext{
32 Muhammad Yaumi, Pendidikan Karakter Landasan, Pilar \& Implementasi, Jakarta, Prenadamadia Group, 2014, hal 3

${ }^{33}$ Masrukhiunnes. Wordpress.com/2015
} 
berlangsung seumur hidup. Itulah sebabnya, perencanaan pembelajaran yang praktis, aplikabel, dan memperhatikan perkembangan dan pertumbuhan peserta didik sangat diperlukan, dalam upaya pembelajaran nilai yang membawa muatan pembangunan karakter.

\section{Kesimpulan}

Pelaksanaan pendidikan karakter memiliki permasalahan tersendiri, yaitu adanya ketidaksinkronan antara konsep pendidikan karakter, yang bertujuan untuk mengembalikan budaya dan karakter bangsa yang semakin merosot dengan realita yang dihadapi. Pada saat di sekolah ditanamkan nilai-nilai karakter baik, tidak ditunjang dengan kondisi lingkungan yang mencontohkan nilai-nilai yang berseberangan...Menghadapi kondisi Bangsa Indonesia yang mengalami krisis multidimensional akibat terkikisnya nilai-nilai karakter bangsa, dan kekhawatiran lahirnya generasi yang tidak sesuai dengan tujuan pendidikan nasional, generasi yang berkepribadian luhur, menjalankan nilai-nilai agama dan pancasila, maka di buatlah kebijakan dan konsep pendidikan budaya dan karakter bangsa untuk mengembalikan karakter bangsa Indonesia yang religius dan pancasilais. Pendidikan karakter sebagai reformasi pendidikan akan terwujud dengan adanya kerjasama mulai dari pemerintah pusat sebagai pembuat kebijakan, sekolah sebagai pelaksana pendidikan di lapangan yang mengintegrasikan pendidikan karakter dalam kurikulum yang dipergunakan dan gurunya sebagai role model, orang tua sebagai pembentuk pertama karakter anak, dan masyarakat atau lingkungan yang mencerminkan penerapan budaya dan karakter bangsa dalam kehidupan sehari-hari. Keberhasilan pendidikan karakter akan dirasakan manakala semua unsur menjalankan fungsi masing-masing dengan sebaik-baiknya.

Pendidikan karakter di perguruan tinggi tetap diperlukan dalam rangka reshape dan rebuild, melengkapi dan mengokohkan karakter baik yang dibentuk pada tingkat pendidikan sebelumnya.

Implementasi pendidikan karakter dapat dilakukan dengan membentuk program tersendiri atau berjalan seiring kurikulum yang sudah ada. Dalam upaya untuk mencapai keberhasilan implementasi pendidikan karakter di perguruan tinggi maka diperlukan beberapa kondisi pendukung yang bersifat non kurikulum. 


\section{Daftar Pustaka}

Adisusilo, Sutarjo, (2014), Pembelajaran Nilai Karakter, Jakarta, RajaGrafindo Persada Depdikbud, 2002, Kamus Besar Bahasa Indonesia, Jakarta: Bulan Bintang Kemdiknas. (2010). Desain Induk pendidikan Karakter. Jakarta: Kementerian Pendidikan Nasional.

Kemdiknas, B. P. (2011). Panduan Pelaksanaan Pendidikan Karakter. Jakarta: Kemdiknas.

Kemdiknas, D. P. (2010). Konsep Pendidikan Budaya dan Karakter Bangsa. Jakarta: Direktorat

PSMP Kemdiknas

Kompas. (2012, Desember). Dipetik Desember 6, 2012, dari www. http://internasional.kompas.com.

Lickona, Thomas,(2016), Mendidik Untuk Membentuk Karakter, Jakarta, Bumi Aksara Masrukhiunnes.wordpress.com/2015/01/26, implementasi-pendidikan-karakter-dalamperkuliahan

Melinda,CB.,Berkowitz MW. (2005), What Work in Character Education? Leadership For Students Activities, October 2005, vol 34, no 2, page 1-7

Rosyid, M Ainur, (2017), Hadits-Hadits Tarbawi, Yogyakarta Diva Press.

Sartono. (2011). Pengintegrasian Pendidikan Karakter dalam Pengembangan Kurikulum Tingkat

Satuan Pendidikan. Makalah Disertasi , 6.

Samani, Muchlas \& Hariyanto, (2016), Pendidikan Karakter, Bandung, Remaja Rosdakarya Schwartz, AJ. (2000). It's Not to Late to Teach College Student about Values. The Chronicle of

Higher Education. Vol. 46 No. 40.pg A68

Shochib, Moh, (2014), Pola Asuh Orang Tua Dalam Membantu Anak Mengembangkan Disiplin

Diri Sebagai Pribadi Yang Berkarakter, Jakarta Rineka Cipta

Syukri, (2009), Peran Pendidikan di Perguruan Tinggi terhadap Perubahan Perilaku Kaum

Intelektual (social-Individu). Jurnal Ilmiah Kreatif Vol 6 No 1, hal 1-15

Syukir, 1983, Dasar-dasar Strategi Dakwah Islam, Surabaya, Al-Ikhlas.

Yaumi, Muhammad,(2014), Pendidikan Karakter Landasan Pilar \& Implementasi, Jakarta, Prenadamedia Group 